\title{
Nucleic acid ratio as a proxy for starvation of coastal and pelagic copepods in the North Pacific Ocean
}

\author{
Toru Kobari ${ }^{1, *}$, Sachi Miyake ${ }^{2}$, William T. Peterson ${ }^{3}$, Jay Peterson $^{4} \&$ Tracy Shaw ${ }^{5}$ \\ ${ }^{1}$ Aquatic Sciences, Faculty of Fisheries, Kagoshima University, 4-50-20 Shimoarata, Kagoshima 890-0056, Japan \\ ${ }^{2}$ Aquatic Sciences, Graduate School of Fisheries, Kagoshima University, 4-50-20 Shimoarata, Kagoshima 890-0056, Japan \\ ${ }^{3}$ Northwest Fisheries Science Center, National Oceanic and Atmospheric Administration, 2030 SE Marine Science Drive, New- \\ port, OR 97365, USA \\ ${ }^{4}$ Office of Science and Technology, National Oceanic and Atmospheric Administration, 1315 East-West Hwy., Silver Spring, MD \\ 20910, USA \\ ${ }^{5}$ University of South Florida, College of Marine Science, 140 7th Avenue S., St. Petersburg, FL 33701, USA
}

Received 1 August 2016; Accepted 1 November 2016 Responsible Editor: Koichi Ara

\begin{abstract}
We investigated the nucleic acid ratio (RNA/DNA) as a proxy for starvation in copepods collected from coastal and pelagic sites across the North Pacific Ocean. While RNA/DNA ratios were variable among copepod species and their life stages, lower ratios were found for the copepods collected from the Kuroshio region compared to ones from the western subarctic site of the North Pacific Ocean. Log-transformed RNA/DNA ratios showed a negative correlation to log-transformed mean temperature in the sampling layer and a positive correlation to log-transformed chlorophyll $a$ concentrations. Copepod incubation experiments demonstrated that RNA/DNA ratios significantly declined after exposure to starvation and the decline was greater for the copepods collected from the subtropical sites compared with those from the subarctic. However, no significant decline was found for some species and stages accumulating lipids. These findings suggest that copepod RNA/DNA ratios are associated with food availability but are not sensitive to starvation for some copepods accumulating lipids.
\end{abstract}

Key words: copepods, DNA, RNA, starvation, lipids

\section{Introduction}

Pelagic calanoid copepods are crustacean zooplankton showing a high species diversity, with more than 2000 species world-wide (Razouls et al. 2005-2013). They are a significant component of the zooplankton community in terms of both abundance (Longhurst 1985) and biomass in the world's oceans (Verity \& Smetacek 1996). The material and energy flows within aquatic food webs are influenced by their feeding on not only phytoplankton, but also protozoans and sinking particles (e.g., Dagg 1993, Kobari et al. 2003a). The pelagic calanoid copepods are also major food resources for fishes, mammals and sea birds (e.g., Hunt et al. 1998, Moku et al. 2000, Yamamura et al. 2002). Thereby, their population dynamics are important for understanding trophodynamics in marine ecosystems.

Population dynamics of copepods are largely deter-

* Corresponding author: Toru Kobari; E-mail, kobari@fish.kagoshima-u. ac.jp mined by their growth and mortality. For the last half century, a great deal of effort has been dedicated to increasing knowledge on zooplankton growth, estimated by techniques such as frequent field sampling (e.g., Heinle 1966, Liang et al. 1996, Kobari et al. 2010) and ship-board or laboratory incubations (e.g., Burkill \& Kendall 1982, Kimmerer \& McKinnon 1987, Berggreen et al. 1988). On the other hand, zooplankton mortality is difficult to estimate due to the population variables being strongly influenced by the diffusion and advection of water masses (field sampling) and difficulty excluding predators in the incubation techniques (see Hirst \& Kiørboe 2002). While cohort analysis with frequent sampling provides information on mortality (Ohman \& Hirche 2001), the practical application to pelagic zooplankton is logically much more difficult.

Biochemical approaches have been used for understanding physiological processes of zooplankton for the last two decades (e.g., Oosterhuis et al. 2000, Sastri \& Roff 2000, Wagner et al. 2001, Yebra \& Hernández-Léon 2004). Among the biochemical approaches, nucleic acid- 
based indices have been most commonly applied in various metazoan species as proxies of individual physiological condition, reproductive activity and somatic growth (see Yebra et al. in press). The nucleic acid ratio (RNA/ DNA) is suggested as a proxy of feeding history, including starvation, because nucleic acids are functioning in the first steps of protein synthesis and cellular contents of nucleic acids vary with protein synthesis activity (e.g., Gorokhova \& Kyle 2002, Speekmann et al. 2007, Holmborn et al. 2009). Starvation is considered to increase copepod mortality risks due to the reduction of their swimming activity (Mackas \& Burns 1986). Although biochemical approaches have been applied for identifying starvation in naturally occurring larvae of pelagic fishes and gastropods (e.g., Chícharo et al. 1998, Vidal et al. 2006) and incubated copepods of coastal species (e.g., Saiz et al. 1998, Speekmann et al. 2007), we have little information on its potential use for pelagic zooplankton species in nature.

In the present study, we investigated geographical variations in individual contents of RNA to those of DNA for copepods collected from coastal to pelagic sites across the North Pacific Ocean, in order to investigate how nucleic acid ratios of coastal to pelagic copepods change under the ambient temperature and food supply. Moreover, we compared changes in RNA/DNA ratios of several species and developmental stages of copepods, following exposure to starvation conditions (i.e., no food supply), to determine if particular geographic regions and life-history stages are more susceptible to low food concentrations. From these results, we discuss the potential use of RNA/DNA ratios as a proxy of starvation in copepods.

\section{Materials and Methods}

\section{Oceanographic observations and sample collections}

Oceanographic observations and sample collections were conducted during cruises on the R/V Elakha from May to August 2012 off the Oregon coast in the eastern North Pacific (NH5, HN20, NH25, NH35, NH45 and NH65), the R/V Mirai from June to August 2011 at subtropical (S1) and subarctic (K2) sites in the western North Pacific Ocean, the T/S Nansei-Maru during May 2012 in Kagoshima Bay (KB1 to KB15), and the T/S KagoshimaMaru during November 2012 in the Kuroshio region (KR4 to KR9) (Fig. 1). Temperature, salinity and chlorophyll fluorescence was recorded from the sea surface to $100 \mathrm{~m}$ using a CTD system. Water samples for chlorophyll measurements were collected with a plastic bucket from the sea surface in the eastern North Pacific or a CTD-CMS system at 7 discrete depths $(0,10,20,30,50,75,100 \mathrm{~m})$ in the western North Pacific. These samples were filtered through Whatman GF/F filters and chlorophyll pigments were extracted with $90 \%$ Acetone (eastern North Pacific) or $\mathrm{N}, \mathrm{N}$ dimethylformamide (western North Pacific). Chlorophyll $a$ concentration was measured with a fluorometer (10-AU, Turner Designs, USA) by the acidified fluorometric method (Holm-Hansen et al. 1965) (eastern North Pacific) or the non-acidified fluorometric method (Welschmeyer 1994) (western North Pacific). Chlorophyll fluorescence was calibrated with the observed chlorophyll $a$ concentrations.

We collected copepods from the upper $25 \mathrm{~m}$ using a Bongo net with a $2 \mathrm{~L}$ cod end (diameter $60 \mathrm{~cm}$, mesh size $0.335 \mathrm{~mm}$ ) (eastern North Pacific) or from the upper $100 \mathrm{~m}$ using a North Pacific Standard net with a $3 \mathrm{~L}$ cod (diameter $45 \mathrm{~cm}$, mesh size $0.335 \mathrm{~mm}$ ) (western North Pacific). Bongo (obliquely) and North Pacific Standard (vertically)

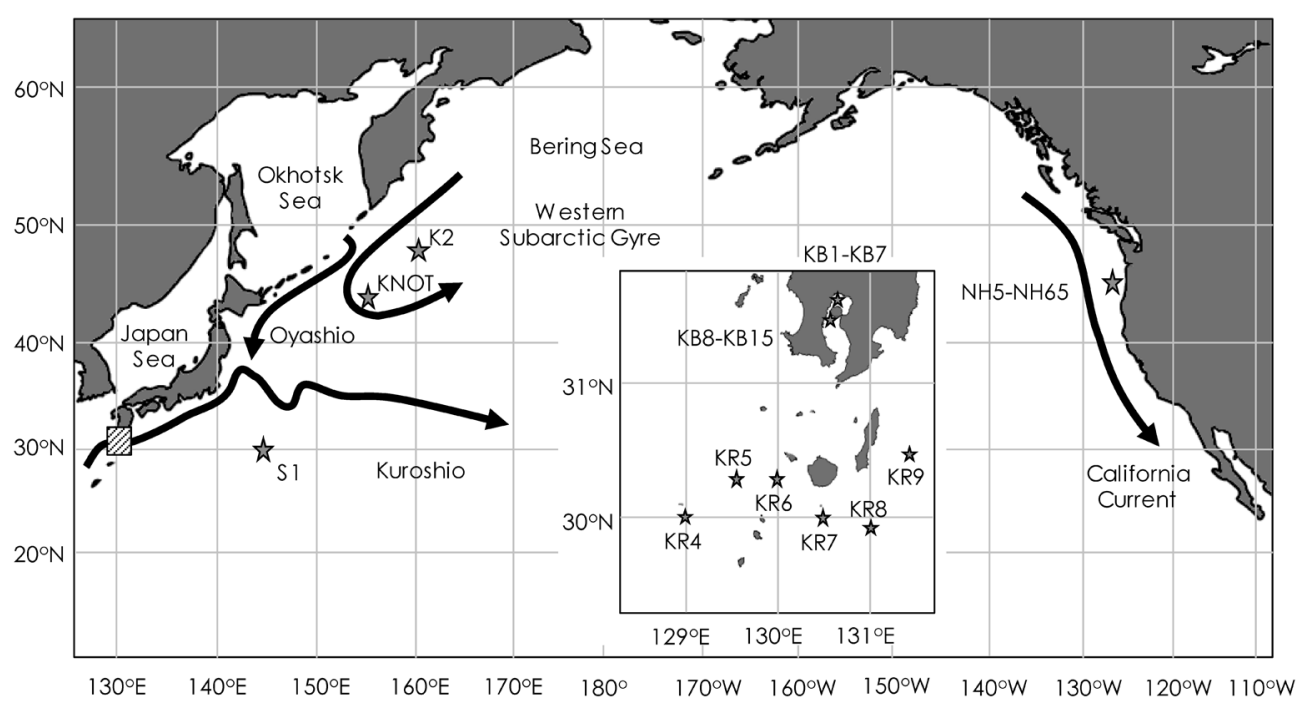

Fig. 1. Sampling stations in the eastern (NH5-NH65) and western (K2, S1, KNOT, KR4-KR9, KB1-KB15) North Pacific Ocean. Shaded box shows Kuroshio area enlarged in the map. Current systems are superimposed. 
nets were towed at a speed of 0.5 to $1 \mathrm{~m} \mathrm{sec}^{-1}$. After collection, the predominant copepods among the zooplankton community were identified to species and developmental stage under a dissecting microscope. For the incubation experiments, individual copepod was put into a $500 \mathrm{~mL}$ polycarbonate bottle containing filtered seawater (pore size: $0.7 \mu \mathrm{m}$ ). For geographical comparisons of RNA/DNA ratios, individual copepods were put into a $2 \mathrm{~mL}$ vial and preserved at $-80^{\circ} \mathrm{C}$ until analysis.

\section{Incubations}

For comparing the response of the nucleic acid ratio to starvation, we incubated copepods collected from the subtropical and subarctic sites in the western North Pacific under starvation conditions. Individuals (up to 50 animals) of the dominant species and life stages were transferred into a $500 \mathrm{~mL}$ polycarbonate bottle containing filtered seawater (pore size: $0.7 \mu \mathrm{m}$ ) and incubated under dark conditions at $20^{\circ} \mathrm{C}$ for $2 \mathrm{~d}$ at $\mathrm{S} 1$ and at $5^{\circ} \mathrm{C}$ for $5 \mathrm{~d}$ at $\mathrm{K} 2$. Due to the slow physiological responses to starvation exposure at low temperature for the subarctic copepods, the incubation duration at $\mathrm{K} 2$ was prolonged to be able to compare the metabolic consumption between the subarctic and subtropical copepods using the empirical model of Ikeda et al. (2001) (i.e., $2 \mathrm{~d}$ at $\mathrm{S} 1$ and $5 \mathrm{~d}$ at K2). At the beginning and the end of the experiments, the individual copepods were put into $2 \mathrm{~mL}$ vials and stored at $-80^{\circ} \mathrm{C}$ until analysis.

For comparing the response of the nucleic acid ratio to starvation among animals of different body mass (i.e., lipid storage), we collected copepods that accumulate lipids from the eastern North Pacific. Individual species and life stages (up to 50 animals) were transferred into $500 \mathrm{~mL}$ polymethylpentene bottles containing filtered seawater (pore size: $0.2 \mu \mathrm{m}$ ) and incubated at $11^{\circ} \mathrm{C}$ under dark conditions. Due to the different body masses, we needed to standardize the starvation duration for each copepod. Since copepods metabolize their body carbon for respiratory requirements under starvation exposure, starvation duration ( $D$ : days) can be standardized using the following equation:

$$
D=N G E \times A C W / R C,
$$

where $N G E$ is net growth efficiency, $A C W$ is animal carbon weight (mg ind. ${ }^{-1}$ ), and $R C$ is respiratory consumption ( $\mu \mathrm{g} \mathrm{C}$ ind. ${ }^{-1} \mathrm{~d}^{-1}$ ) estimated at ambient temperature (WT: $\left.{ }^{\circ} \mathrm{C}\right)$. Therefore, $D$ was necessary for the determination of incubation period for the copepods. $N G E$ and gross growth efficiencies $(G G E)$ are defined by the following equations, respectively (Omori \& Ikeda, 1984):

$$
\begin{gathered}
N G E=N P /(N P+R C), \\
G G E=N P \times A E /(N P+R C),
\end{gathered}
$$

where $N P$ is net production ( $\mu \mathrm{g} \mathrm{C}$ ind..$\left.^{-1} \mathrm{~d}^{-1}\right)$ and $A E$ is assimilation efficiency. Thus, $N G E$ can be transformed following the equation:

$$
N G E=G G E / A E .
$$

Assuming 0.3 for $G G E$ and 0.7 for $A E$ (Omori \& Ikeda 1984), $N G E$ is estimated to be 0.43 . If copepod $N G E$ under starvation exposure is lower than 0.43 , they metabolize more body carbon for their respiratory requirements than ingested carbon. Thus, we define $N G E$ of 0.43 of as the starvation point. Assuming 0.4 for the carbon content (Peters \& Downing 1984) and 0.7 for the respiratory quotient (lipid metabolism: Omori \& Ikeda 1984), $A C W$ and $R C$ were estimated as per the following equations:

$$
\begin{gathered}
A C W=0.4 \times 10^{(1.1623 \times \log (P L)-1.688)} \\
R C=0.7 \times R O \times 12 / 22.4
\end{gathered}
$$

where $P L$ is prosome length $(\mathrm{mm})$ and $R O$ is oxygen consumption $\left(\mu \mathrm{L} \mathrm{O}_{2}\right.$ ind $\left.^{-1} \mathrm{~h}^{-1}\right)$ estimated with the empirical model (Ikeda et al. 2001):

$$
R O=\exp [0.124+0.780 \times \ln (A C W)+0.073 \times(W T)] \times 24
$$

\section{Nucleic acids analyses}

RNA and DNA were measured following the microplate fluorescent assay (MFA) developed by Wagner et al. (1998). The MFA assay is a modification of the sequential fluorometric method of Bentle et al. (1981), in which DNA and RNA in a single sample are determined sequentially by the addition of DNase and RNase using EB as the fluorescent dye (see Caldarone et al. 2006 for details). Wagner et al. (1998) modified the sequential fluorometric method to the MFA with 96-well microtiter plates by adopting a sarcosyl extraction technique and eliminating the DNase step, thus allowing application of the assay to small samples (single copepods) without extended working time.

Each specimen was thawed and then homogenized by vigorous shaking with 5 zirconia beads and 1\% sarcosyl extraction buffer. The volume of the extraction buffer was $200 \mu \mathrm{L}$. The samples were shaken for $20 \mathrm{~min}$ at room temperature on a vortex mixer equipped with a multiple-vial head. The samples were then diluted with Tris buffer to reduce the sarcosyl concentration to $0.1 \%$, and were shaken again for $40 \mathrm{~min}$. They were then centrifuged (15000 g) for $10 \mathrm{~min}$ at $4^{\circ} \mathrm{C}$ to separate insoluble copepod remains.

In each run, a $100 \mu \mathrm{L}$ aliquot of supernatant from each sample was transferred to 96-well microplates (Nunc) along with 8 replicates from 0.15 to $5.0 \mu \mathrm{g} \mathrm{mL}^{-1}$ of DNA (calf-thymus, Sigma-Aldrich D4522) and 0.15 to $10 \mu \mathrm{g} \mathrm{mL}^{-1}$ RNA (bakers-yeast, Sigma-Aldrich R7125) to generate standard curves. The zero concentration of the standard solutions can also be regarded as reagent blanks (containing all chemicals but no copepod homogenates). In the present study, we used SYBR Green I (Sigma-Aldrich S9430) as a fluorescent dye due to its higher sensitivity to nucleic acids and safety than the Ethidium bromide used by Wagner et al. (1998). $100 \mu \mathrm{L}$ of $0.1 \%$ SYBER Green I was added to each well, and the plates were placed at 
room temperature for $20 \mathrm{~min}$. The SYBR Green fluorescence was then scanned on a microplate reader (PerkinElmer, ARVO MX1420) with $485 \mathrm{~nm}$ (excitation) and $535 \mathrm{~nm}$ (emission) filters (First scan). RNase solution $(10 \mu \mathrm{L})$ was added to each well. The microplate was left at room temperature for $15 \mathrm{~min}$ and the SYBER Green fluorescence was scanned a second time. RNA concentrations $\left(\mu \mathrm{g} \mathrm{mL}^{-1}\right)$ were calculated as the differences between the first (DNA+RNA) and second (DNA) scans, and the standard curve of RNA versus the fluorescence established from the first scan of the same plate. DNA concentrations $\left(\mu \mathrm{g} \mathrm{mL}^{-1}\right)$ were computed from the second scan and the standard curve of DNA versus fluorescence established during the second scan (RNase treated) of the same plate.

\section{Data analysis}

All statistical calculations were done by using Excel Statistics 2012 for Windows (SSRI Co., Ltd.). The effects of water temperature and food availability on individual RNA/DNA ratios were evaluated by the Pearson productmoment correlation coefficient. The significant difference of RNA/DNA ratio before and after the starvation exposure was determined by Welch's $t$-test. We also determined the significant decline in individual contents of RNA to those of DNA after the starvation exposure by ANCOVA.

\section{Results}

\section{Geographical variations}

Regional differences were found for the water temperatures and chlorophyll $a$ concentrations averaged in the sampling layers (Fig. 2). The lower water temperatures were evident at the subarctic sites (K2, KNOT and Oregon coast), compared with those at the subtropical sites
(S1 and Kuroshio area) where the chlorophyll $a$ concentrations were low. Individual RNA/DNA ratios of the copepods collected from the eastern and western North Pacific Ocean demonstrated geographical variations (Fig. 3). The RNA/DNA ratios were also variable among the copepod species and their life stages. The ratios were higher than 4.2 at $\mathrm{K} 2$ and lower than 2.7 in the Kuroshio region, while they ranged from 1.7 to 5.3 at the other sites. Due to the species- and stage-specific variability, log-transformed values of the RNA/DNA ratio ( $\log R \mathrm{D})$ were computed and then compared with log-transformed values of the temperature (LogWT) and chlorophyll $a$ concentrations averaged in the sampling layers (LogCHL). LogRD showed a significantly negative correlation to LogWT (Pearson productmoment correlation coefficient, $r=-0.491, p<0.01$ ) and a positive correlation to LogCHL (Pearson product-moment correlation coefficient, $r=0.185, p<0.01$ ) (Fig. 4), while a

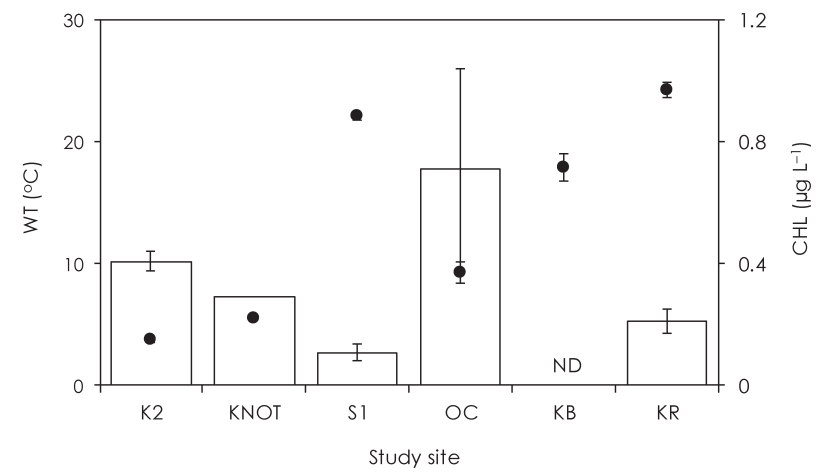

Fig. 2. Regional differences in water temperatures $\left({ }^{\circ} \mathrm{C}\right.$ : closed symbols) and chlorophyll $a$ concentrations ( $\mu \mathrm{g} \mathrm{L}^{-1}$ : open bars) averaged in the sampling layers among the study sites. Vertical bars show standard deviations. ND: No data. OC: Oregon coast. KB: Kagoshima Bay. KR: Kuroshio area.

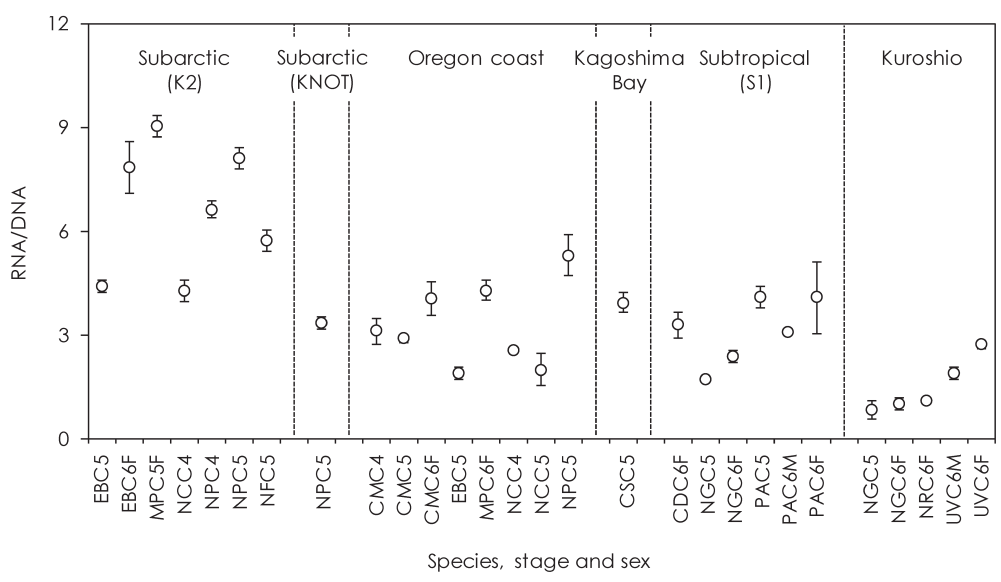

Fig. 3. Geographical variations in RNA/DNA ratios for copepods collected from the eastern and western North Pacific Ocean. Vertical bars show standard errors. Abbreviations are spelled as copepod species, stage and sex. CD: Cosmocalanus darwinii. CM: Calanus marshallae. CS: C. sinicus. EB: Eucalanus bungii. MP: Metridia pacifica. NC: Neocalanus cristatus. NF: N. flemingeri. NG: N. gracilis. NP: N. plumchrus. PA: Pleuromamma abdominalis. NR: N. robstrior. UV: Undinulla vulgaris. C4: Copepodite stage 4. C5: Copepodite stage 5. C6: Adult. F: Female. M: Male. 

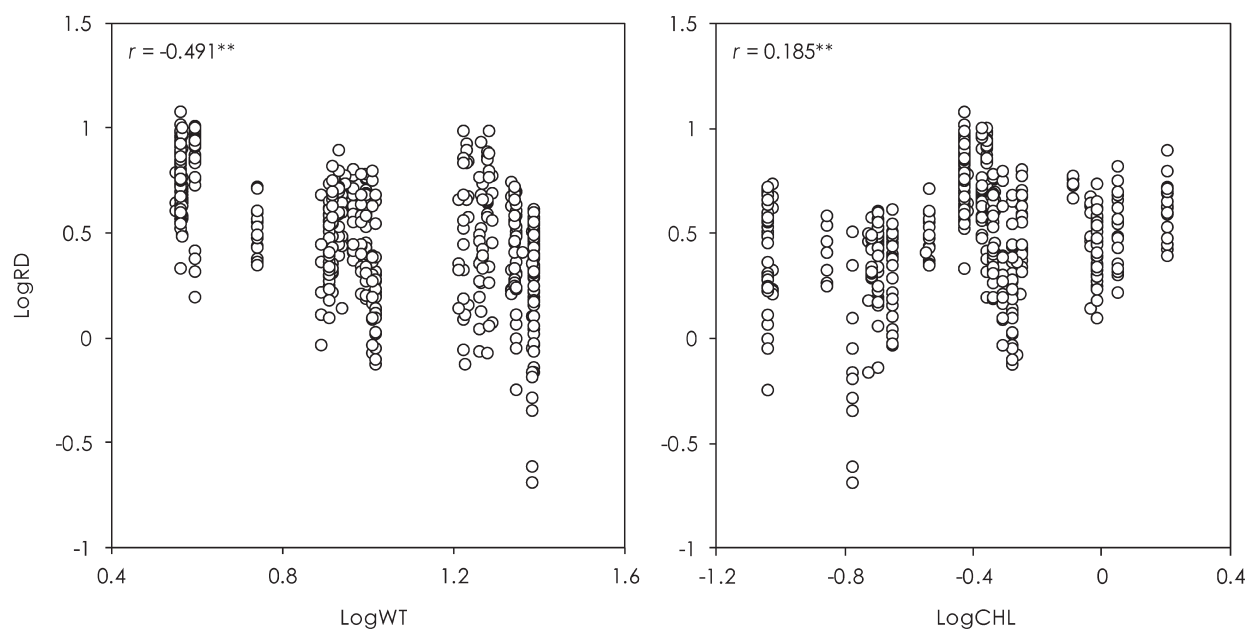

Fig. 4. Comparisons of log-transformed RNA/DNA (LogRD) ratios for copepods collected from the eastern and western North Pacific Ocean to log-transformed mean temperature (LogWT) or chlorophyll $a$ concentration in the sampling layer (LogCHL). $r$ : Pearson productmoment correlation coefficient. ${ }^{* *} p<0.01$.

Table 1. Changes in RNA/DNA ratios of subarctic (K2) and subtropical (S1) copepods between before (To: just after collection) and after starvation exposure (Ta).

\begin{tabular}{|c|c|c|c|c|c|c|c|}
\hline \multirow{3}{*}{$\begin{array}{l}\text { Area } \\
\quad \text { Species }\end{array}$} & \multirow{3}{*}{ Stage } & \multirow{3}{*}{ Sex } & \multirow{3}{*}{$\mathrm{D}$} & \multicolumn{4}{|c|}{ RNA/DNA } \\
\hline & & & & \multicolumn{2}{|c|}{ To } & \multicolumn{2}{|l|}{$\mathrm{Ta}$} \\
\hline & & & & $\mathrm{M} \pm \mathrm{SE}$ & $n$ & $\mathrm{M} \pm \mathrm{SE}$ & $n$ \\
\hline \multicolumn{8}{|l|}{ Subarctic (K2) } \\
\hline \multirow[t]{2}{*}{ Eucalanus bungii } & $\mathrm{C} 5$ & $\mathrm{~F}$ & 5 & $4.37 \pm 0.19$ & 18 & $3.88 \pm 0.17$ & 19 \\
\hline & C6 & $\mathrm{F}$ & 5 & $8.42 \pm 0.56$ & 5 & $5.35 \pm 0.84^{*}$ & 5 \\
\hline Metridia pacifica & C6 & $\mathrm{F}$ & 5 & $8.95 \pm 0.33$ & 17 & $7.33 \pm 0.64^{*}$ & 16 \\
\hline \multirow[t]{2}{*}{ Neocalanus cristatus } & $\mathrm{C} 4$ & - & 5 & $4.36 \pm 0.30$ & 19 & $2.89 \pm 0.24^{* *}$ & 11 \\
\hline & $\mathrm{C} 5$ & - & 5 & $2.67 \pm 0.37$ & 6 & $2.96 \pm 0.14$ & 16 \\
\hline N. flemingeri & $\mathrm{C} 5$ & - & 5 & $5.74 \pm 0.35$ & 15 & $2.88 \pm 0.28^{* *}$ & 13 \\
\hline \multirow[t]{2}{*}{ N. plumchrus } & $\mathrm{C} 4$ & - & 5 & $6.65 \pm 0.25$ & 20 & $4.80 \pm 0.19^{* *}$ & 18 \\
\hline & $\mathrm{C} 5$ & - & 5 & $8.07 \pm 0.32$ & 20 & $6.81 \pm 0.19^{* *}$ & 21 \\
\hline \multicolumn{8}{|l|}{ Subtropical (S1) } \\
\hline Cosmocalanus dawini & $\mathrm{C} 5$ & - & 2 & $3.42 \pm 0.39$ & 18 & $1.93 \pm 0.62^{*}$ & 3 \\
\hline \multirow[t]{2}{*}{ Neocalanus gracilis } & $\mathrm{C} 5$ & - & 2 & $1.73 \pm 0.05$ & 5 & $0.82 \pm 0.33$ & 3 \\
\hline & C6 & $\mathrm{F}$ & 2 & $2.44 \pm 0.22$ & 4 & $0.74 \pm 0.15^{* *}$ & 4 \\
\hline \multirow{2}{*}{ Pleuromama abdominalis } & $\mathrm{C} 5$ & - & 2 & $4.09 \pm 0.30$ & 7 & $1.67 \pm 0.29^{* *}$ & 2 \\
\hline & C6 & $\mathrm{F}$ & 2 & $4.72 \pm 0.96$ & 4 & $2.03 \pm 0.44^{*}$ & 4 \\
\hline
\end{tabular}

D: Incubation period in days under starvation conditions. C: Copepodite stage. F: Female. M: Mean. SE: Standard error. $n$ : Number of individuals.

${ }^{*} p<0.05$ (Welch's $t$-test). ${ }^{* *} p<0.01$ (Welch's $t$-test).

significant negative correlation was found between LogWT and $\log$ CHL (Pearson product-moment correlation coefficient, $r=-0.537, p<0.01)$.

\section{Exposure to starvation}

The individual RNA/DNA ratios for both the subarctic and subtropical copepods were changed before (i.e., just after collection) and after exposure to starvation (Table 1). The RNA/DNA ratios before exposure were vari- able among the copepod species and their life stages, and ranged from 1.7 to 9.0. After starvation, the RNA/DNA ratios significantly declined for most of the copepod species and stages (Welch's $t$-test, $p<0.05$ ), with the exception being $\mathrm{C} 5$ stages of $E$. bungii, $N$. cristatus and $N$. gracilis (Welch's $t$-test, $p>0.05$ ). Compiling all species and stages, a general decline of log-transformed RNA (LogRNA) to log-transformed DNA (LogDNA) was found for both subarctic and subtropical copepods after exposure to starva- 

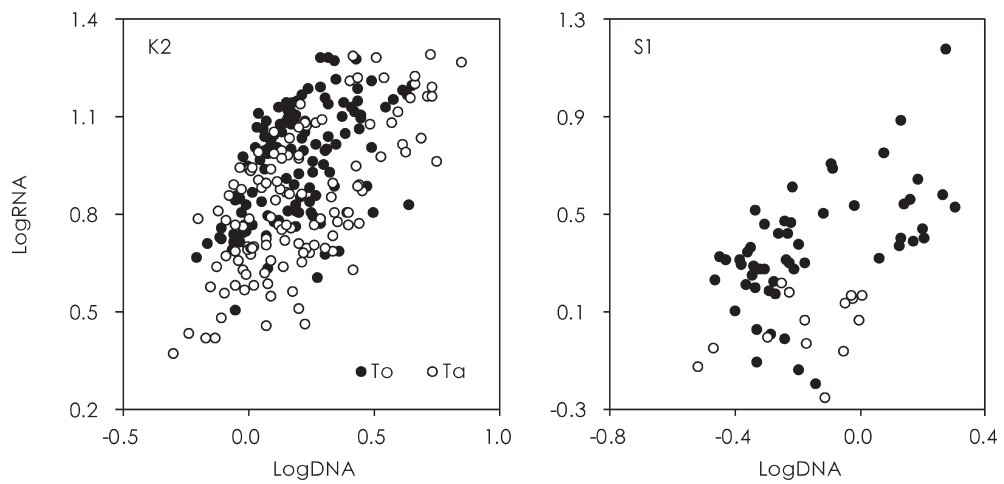

Fig. 5. Comparisons of log-transformed RNA contents (LogRNA) to log-transformed DNA contents (LogDNA) for the subarctic (K2) and subtropical (S1) copepods between before (To: closed circles) and after (Ta: opened circles) exposure to starvation.

Table 2. Summary of results for analysis of covariance (ANCOVA) for difference of log-transformed RNA contents (LogRNA) in subarctic (K2) and subtropical (S1) copepods between experimental conditions (before and after starvation) on log-transformed DNA contents (LogDNA) as a covariate.

\begin{tabular}{lrrrrrr}
\hline \multicolumn{1}{c}{ Source } & $\begin{array}{c}\text { Sum of } \\
\text { Squares }\end{array}$ & df & $\begin{array}{c}\text { Mean } \\
\text { Square }\end{array}$ & $F$ value & $p$ \\
\hline K2 & & & & & \\
$\quad$ Starvation (To or Ta) & 0.64 & 1 & 0.64 & 26.36 & $<0.01$ \\
LogDNA & 3.09 & 1 & 3.09 & 127.63 & $<0.01$ \\
Starvation*LogDNA & 0.01 & 1 & 0.01 & 0.58 & 0.43 \\
Error & 5.86 & 242 & 0.02 & & \\
$\quad$ Total & 10.32 & 245 & & & \\
S1 & & & & & \\
Starvation (To or Ta) & 1.07 & 1 & 1.07 & 20.48 & $<0.01$ \\
$\quad$ LogDNA & 0.30 & 1 & 0.30 & 5.77 & $<0.01$ \\
Starvation*LogDNA & 0.03 & 1 & 0.03 & 0.66 & 0.38 \\
Error & 3.46 & 66 & 0.05 & & \\
$\quad$ Total & 6.24 & 69 & & & \\
\hline
\end{tabular}

To: Before starvation. Ta: After starvation.

tion (Fig. 5). However, the decline after starvation was less for the subarctic copepods compared with those for the subtropical ones. According to the results for analysis of covariance (ANCOVA: Table 2), no significant interaction was evident for LogRNA to $\log$ DNA before and after the starvation, indicating that the decline of the RNA contents was not associated with the DNA contents.

Next, we investigated the decline of the RNA/DNA ratios after exposure to starvation using the subarctic copepods collected from the Oregon coast, which had accumulated lipids. The RNA/DNA ratios before starvation were variable among the copepod species and stages, and ranged from 1.3 to 5.4 (Table 3). No significant decline (Welch's $t$-test, $p>0.05$ ) of the RNA/DNA ratios after starvation was observed for more than half of the cases. Compiling all species and stages (Fig. 6), a decline in LogRNA to LogDNA was not clear for these copepods after exposure to starvation. The results of ANCOVA demonstrated that significant interaction was evident for LogRNA to LogDNA before and after the starvation (Table 4), indicating less decline of the RNA contents for the copepods with the higher DNA contents.

\section{Discussion}

Even though the RNA/DNA ratios were species- and stage-specific, lower ratios were found for copepods collected from the Kuroshio region compared with those from the other sites (Fig. 3). The geographical variations are partially explained by mean water temperature and chlorophyll $a$ in the sampling layer (Fig. 4). These findings are consistent with previous results using copepod cultures, where the ratios showed a negative correlation to temperature (Ota \& Landry 1984, Wagner et al. 2001) and a positive correlation to food concentration (Ota \& Landry 1984, Wagner et al. 1998, Gusmão \& McKinnon 2009, Holmborn et al. 2009). As suggested by Wagner et al. (1998, 2001), the positive and negative correlations are likely to be due to enhanced chemical reactions with lower enzyme or RNA concentrations at higher temperature and increased substrates for protein synthesis, respectively. In the present results, high water temperatures $\left(23.1\right.$ to $\left.24.7^{\circ} \mathrm{C}\right)$ and low chlorophyll $a$ concentrations in the sampling layer (0.17 to $0.28 \mu \mathrm{g} \mathrm{L}^{-1}$ ) were evident for the Kuroshio regions where the RNA/DNA ratios were the lowest. Based on the correlation coefficients (Fig. 4), nucleic acid ratios were more correlated with the temperature (WT) than the chlorophyll $a$ concentration (CHL). These results suggest that copepods under warm and oligotrophic conditions are more susceptible to starvation compared with those under colder and eutrophic environments and ambient temperature is more important than food availability.

In our experiments under starvation conditions, a significant decrease in the RNA/DNA ratios was not found for $E$. bungii $\mathrm{C} 5$ and $\mathrm{C} 6, N$. cristatus $\mathrm{C} 5$ and $N$. gracilis $\mathrm{C} 5$ (Table 1). RNA concentrations are more prone to decrease during starvation exposure than DNA, which is more conservative (Saiz et al. 1998, Speekmann et al. 2007), but decline of individual DNA content is also known for some 
Table 3. Changes in RNA/DNA ratios of calanoid copepods collected from the Oregon coast between before (To) and after starvation (Ta).

\begin{tabular}{|c|c|c|c|c|c|c|c|c|}
\hline \multirow{3}{*}{ Species } & \multirow{3}{*}{ Stage } & \multirow{3}{*}{ Sampling date } & \multirow{3}{*}{ Station } & \multirow{3}{*}{$\mathrm{D}$} & \multicolumn{4}{|c|}{ RNA/DNA } \\
\hline & & & & & \multicolumn{2}{|l|}{ To } & \multicolumn{2}{|l|}{$\mathrm{Ta}$} \\
\hline & & & & & $\mathrm{M} \pm \mathrm{SE}$ & $n$ & $\mathrm{M} \pm \mathrm{SE}$ & $n$ \\
\hline \multirow[t]{11}{*}{ Calanus marshallae } & $\mathrm{C} 4$ & 20120720 & $\mathrm{NH} 25$ & 7.8 & $2.01 \pm 0.07$ & 4 & $1.47 \pm 0.21$ & 4 \\
\hline & & 20120807 & NH5 & 8.0 & $4.98 \pm 0.15$ & 5 & $2.17 \pm 0.21 *$ & 5 \\
\hline & $\mathrm{C} 5$ & 20120625 & NH5 & 8.1 & $3.78 \pm 0.31$ & 8 & $3.51 \pm 0.51$ & 8 \\
\hline & & & NH5 & 8.8 & $3.78 \pm 0.31$ & 8 & $2.26 \pm 0.21^{*}$ & 10 \\
\hline & & 20120707 & NH5 & 8.6 & $2.27 \pm 0.70$ & 5 & $1.66 \pm 0.20$ & 6 \\
\hline & & 20120720 & NH5 & 8.8 & $3.52 \pm 0.36$ & 9 & $2.02 \pm 0.34^{*}$ & 5 \\
\hline & & & $\mathrm{NH} 25$ & 8.8 & $2.56 \pm 0.25$ & 9 & $2.02 \pm 0.11$ & 5 \\
\hline & & 20120722 & NH35 & 8.8 & $1.29 \pm 0.19$ & 4 & $1.75 \pm 0.15$ & 5 \\
\hline & & 20120807 & NH25 & 8.8 & $2.42 \pm 0.14$ & 5 & $0.97 \pm 0.14^{*}$ & 5 \\
\hline & & 20120821 & NH5 & 8.7 & $2.66 \pm 0.28$ & 15 & $1.25 \pm 0.13^{*}$ & 6 \\
\hline & $\mathrm{C} 6 \mathrm{~F}$ & 20120625 & NH5 & 9.0 & $5.36 \pm 0.82$ & 5 & $4.26 \pm 0.49$ & 4 \\
\hline Eucalanus bungii & C5 & 20120807 & NH5 & 8.5 & $3.10 \pm 0.64$ & 3 & $3.25 \pm 0.22$ & 3 \\
\hline \multirow[t]{3}{*}{ Metridia pacifica } & $\mathrm{C} 6 \mathrm{~F}$ & 20120720 & $\mathrm{NH} 25$ & 7.5 & $4.14 \pm 0.36$ & 8 & $2.76 \pm 0.45$ & 3 \\
\hline & & 20120722 & NH65 & 7.7 & $3.52 \pm 1.08$ & 4 & $3.31 \pm 0.58$ & 5 \\
\hline & & 20120807 & $\mathrm{NH} 25$ & 7.6 & $4.18 \pm 0.36$ & 3 & $2.02 \pm 0.22^{*}$ & 3 \\
\hline
\end{tabular}

D: Incubation period in days under starvation conditions. C: Copepodite stage. F: Female. M: Mean. SE: Standard error. $n$ : Number of individuals.

* Significant difference at $p<0.05$.

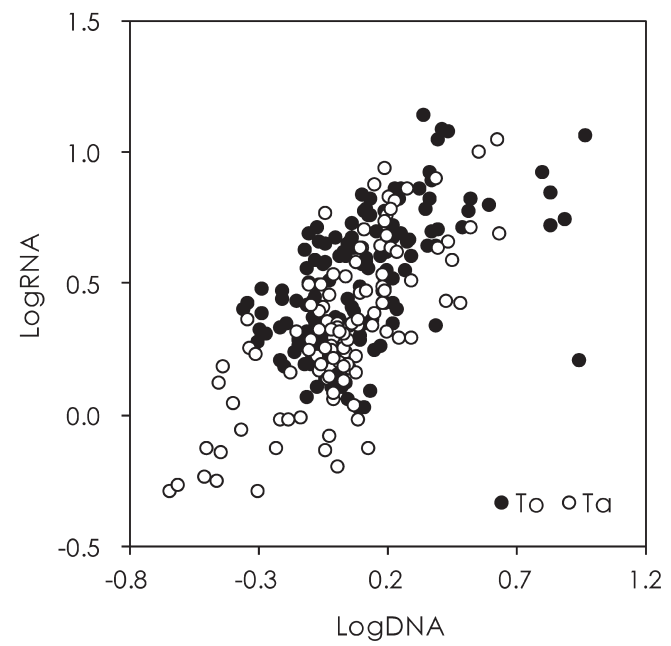

Fig. 6. Comparisons of log-transformed RNA contents (LogRNA) to log-transformed DNA contents (LogDNA) for the copepods collected from Oregon coast between before (To: closed circles) and after (Ta: opened circles) exposure to starvation.

copepod species. Speekmann et al. (2007) reported that a significant decrease of DNA was found for some coastal species even after short periods of starvation, due to cell death. From a methodological point of view, thus, the species-specific changes of DNA content under starvation exposure might be masked by a significant decline in the RNA/DNA ratios for some pelagic copepod species. On the other hand, they were dormant stages and had started their dormancy period during our sampling season (June
Table 4. Summary of results for analysis of covariance (ANCOVA) for difference of log-transformed RNA contents (LogRNA) in copepods collected from the Oregon coast between experimental conditions (before and after starvation) on log-transformed DNA contents (LogDNA) as a covariate.

\begin{tabular}{lrrrrrr}
\hline \multicolumn{1}{c}{ Source } & $\begin{array}{c}\text { Sum of } \\
\text { Squares }\end{array}$ & df & $\begin{array}{c}\text { Mean } \\
\text { Square }\end{array}$ & $F$ value & $p$ \\
\hline Starvation (To or Ta) & 1.87 & 1 & 1.87 & 47.63 & $<0.01$ \\
LogDNA & 7.24 & 1 & 7.24 & 183.94 & $<0.01$ \\
Starvation*LogDNA & 0.21 & 1 & 0.21 & 5.40 & 0.02 \\
Error & 11.14 & 283 & 0.04 & & \\
Total & 21.32 & 286 & & & \\
\hline
\end{tabular}

To: Before starvation. Ta: After starvation.

to July) in neighboring waters (Miller et al. 1984, Kobari \& Ikeda 1999, Tsuda et al. 2004, Shoden et al. 2005, Shimode et al. 2009). Compared with the ratios for dormant specimens of subarctic copepods (Kobari et al. 2013), the RNA/ DNA ratios in our experiments corresponded to those for active specimens, indicating that these copepods could be sensitive to starvation exposure. The compiled data demonstrated that the decline of the RNA/DNA ratios under starvation exposure was less in the subarctic copepods compared to the subtropical ones (Figs. 4, 5). The copepod species and stages that showed no significant decline in the RNA/DNA ratios are also known to accumulate lipids in their body before dormancy (e.g., Kobari and Ikeda 1999, Shoden et al. 2005, Shimode et al. 2009). Taking into account for the use of lipids as alternative metabolic 
substrates (Ikeda 1974), these copepods probably did not exhibit lowered RNA/DNA ratios because they were metabolizing lipid. There are many reports that ambient temperature affects RNA/DNA ratios due to the enzymatic processes of RNA transcription and translation (e.g., Saiz et al. 1998, Gusmão and McKinnon 2011, Wagner et al. 2001). Ambient temperature in our experiments was lower for the subarctic species than the subtropical species, suggesting that the starvation period might not have been long enough for the subarctic copepods to exhibit declining RNA/DNA ratios. In the present study, we also conducted the copepod incubations with standardized starving periods according to their body size, which was positively correlated with body mass due to lipid accumulation (e.g., Kobari et al 2003a, b). The experiments demonstrated that no significant decline of the RNA/DNA ratios was evident for many species and stages (Table 3). However, significant differences were found for the regression equations before and after starvation (Table 4), indicating that RNA contents decline less readily in copepods with high DNA contents (i.e., generally late life stages: Wagner et al. 1998, 2001) after exposure of starvation. Therefore, we suggest that RNA/DNA ratios do not decline in some copepods, even under starvation exposure, due to starvation tolerance imbued by metabolizing accumulated lipids.

The present study showed geographical variations in the RNA/DNA ratios of copepods collected from various sites (i.e., coastal to pelagic, subarctic to subtropical) in the North Pacific Ocean. While the decline of RNA/DNA ratios under starvation exposure has been confirmed in laboratory experiments (e.g., Speekmann et al. 2007), this study is the first to demonstrate that geographical variations in RNA/DNA ratios are likely due to the nutritional conditions associated with ambient temperatures and food availability. Based on the copepod incubations, RNA/ DNA ratios were observed to decrease during starvation exposure except in some copepods that accumulate lipids. These results suggest that RNA/DNA ratios are useful as a proxy for starvation tolerance in natural copepods. Practical applications of RNA/DNA ratios as a proxy for starvation might necessitate further experiments using pelagic copepods exposed to low food availabilities.

\section{Acknowledgements}

We thank Drs. M. C. Honda and M. Kitamura, the captain and crew of the R/V Mirai, T/S Nansei-maru, T/S Kagoshima-maru and R/V Elakha for their help in field samplings. Part of the present study was supported by grants from the Japan Society for the Promotion of Science (25340011), Ministry of Education, Culture, Sports, Science and Technology in Japan (The Study of Kuroshio Ecosystem Dynamics for Sustainable Fisheries: SKED) and from Kagoshima University.

\section{References}

Bentle LA, Dutta S, Metcoff J (1981) The sequential enzymatic determination of DNA and RNA. Anal Biochem 116: 5-16.

Berggreen U (1988) Food size spectra, ingestion and growth of the copepod Acartia tonsa during development: implications for determination of copepod production. Mal Biol 99: 341352.

Burkill PH, Kendall TF (1982) Production of the copepod Eurytemora affinis in the Bristol Channel. Mar Ecol Prog Ser 7: 21-31.

Caldarone EM, Clemmesen CM, Berdalet E (2006) Intercalibration of four spectrofluorometric protocols for measuring RNA/DNA ratios in larval and juvenile fish. Limnol Oceanogr Methods 4: 153-156.

Chícharo MA, Chícharo L, Valdés L, López-Jamar E, Ré P (1998) Estimation of starvation and diet variation of the RNA/ DNA ratios in field-caught Sardina pilchardus larvae off the north of Spain. Mar Ecol Prog Ser 164: 273-283.

Dagg M (1993) Sinking particles as a possible source of nutrition for the large calanoid copepod Neocalanus cristatus in the subarctic Pacific Ocean. Deep-Sea Res I 40: 1431-1445.

Gorokhova E, Kyle M. (2002) Analysis of nucleic acids in Daphnia: development of methods and ontogenetic variations in RNA-DNA content. J Plankton Res 24: 511-522.

Gusmão LM, McKinnon AD (2009) The effect of food type and quantity on egg production and nucleic acid content of Acartia sinjiensis. Aquaculture 296: 71-80.

Gusmão LM, McKinnon AD (2011) Nucleic acid indices of egg production in the tropical copepod Acartia sinjiensis. J Exp Mar Biol Ecol 396: 122-137.

Heinle DR (1966) Production of a Calanoid copepod Acartia ton$s a$ in the Patuxent River estuary. Chesapeake Sci 7: 59-74.

Hirst AG, Kiørboe T (2002) Mortality of marine planktonic copepods: global rates and patterns. Mar Ecol Prog Ser 230: 195-209.

Holmborn T, Dahlgren K, Holeton C (2009) Biochemical proxies for growth and metabolism in Acartia bifilosa (Copepoda, Calanoida). Limnol Oceanogr Methods 7: 785-794.

Holm-Hansen O, Lorenzen CJ, Holmes RW, Strickland JDH (1965) Fluorometric determination of chlorophyll. J Cons Perm Int Explor Mer 30: 3-15.

Hunt GL, Russell RW, Coyle KO, Weingartner T (1998) Comparative foraging ecology of planktivorous auklets in relation to ocean physics and prey availability. Mar Ecol Prog Ser 167: 241-259.

Ikeda T (1974) Nutritional ecology of marine zooplankton. Mem Fac Fish Hokkaido Univ 22: 1-97.

Ikeda T, Kanno Y, Ozaki K, Shinada A (2001) Metabolic rates of epipelagic marine copepods as a function of body mass and temperature. Mar Biol 193: 587-596.

Kimmerer WJ, McKinnon AD (1987) Growth, mortality, and secondary production of the copepod Acartia tranteri in Westernport Bay, Australia. Limnol Oceanogr 32: 14-28.

Kobari T, Ikeda T (1999): Vertical distribution, population structure and life cycle of Neocalanus cristatus (Crustacea: Copepoda) in the Oyashio region, with notes on its regional variations. Mar Biol 134: 683-696. 
Kobari T, Shinada A, Tsuda A (2003a) Functional roles of interzonal migrating mesozooplankton in the western subarctic Pacific. Prog Oceanogr 57: 279-298.

Kobari T, Tadokoro K, Shiomoto A, Hashimoto S (2003b) Geographical variations in prosome length and body weight of Neocalanus copepods in the North Pacific. J Oceanogr 59: $3-10$.

Kobari T, Ueda A, Nishibe Y (2010) Development and growth of ontogenetically migrating copepods during the spring phytoplankton bloom in the Oyashio region. Deep-Sea Res II 57: $1715-1726$.

Kobari T, Mori H, Tokushige H (2013) Nucleic acids and protein content in ontogenetically migrating copepods in the Oyashio region as influenced by development stage and depth distribution. J Plankton Res 35: 97-104.

Liang D, Uye S, Onbé T (1996) Population dynamics and production of the planktonic copepods in a eutrophic inlet of the Inland Sea of Japan. I. Centropages abdominalis. Mar Biol 124: 527-536.

Longhurst AR (1985) Relationship between diversity and the vertical structure of the upper ocean. Deep-Sea Res 32: 1535 1570 .

Mackas DL, Burns KE (1986) Poststarvation feeding and swimming activity in Calanus pacificus and Metridia pacifica. Limnol Oceanogr 31: 383-392.

Miller CB, Frost BW, Batchelder HP (1984) Life histories of large, grazing copepods in a subarctic ocean gyre: Neocalanus plumchrus, Neocalanus cristatus, and Eucalanus bungii in the northeast Pacific. Prog Oceanogr 13: 201-243.

Moku M, Kawaguchi K, Watanabe H, Ohno A (2000) Feeding habits of three dominant myctophid fishes, Diaphus theta, Stenobrachius leucopsarus and S. nannochir, in the subarctic and transitional waters of the western North Pacific. Mar Ecol Prog Ser 207: 129-140.

Ohman MD, Hirche HJ (2001) Density-dependent mortality in an oceanic copepod population. Nature 412: 638-641.

Omori M, Ikeda T (1984) Methods in Marine Zooplankton Ecology. John Wiley \& Sons, New York, 332 pp.

Oosterhuis SS, Baars MA, Breteler WCMK (2000) Release of the enzyme chitobiase by the copepod Temora longicornis: characteristics and potential tool for estimating crustacean biomass production in the sea. Mar Ecol Prog Ser 196: 195-206.

Ota AY, Landry MR (1984) Nucleic acids as growth rate indicators for early developmental stages of Calanus pacificus Brodsky. J Exp Mar Biol Ecol 80: 147-160.

Peters RH, Downing JA (1984) Empirical analysis of zooplankton filtering and feeding rates. Limnol Oceanogr 29: 763-784.

Razouls C, Bovée F, Kouwenberg J, Desreumaux N (2005-2013) Diversity and geographic distribution of marine planktonic co- pepods. Available at: http://copepodes.obs-banyuls.fr/en. (accessed on 31 March 2016)

Sastri AR, Roff JC (2000). Rate of chitobiase decay as a measure of development rate in planktonic Crustacea. Can J Fish Aquat Sci 57: 1965-1968.

Saiz E, Calbet A, Fara A, Berdalet E (1998) RNA content of copepods as a tool for determining adult growth rates in the field. Limnol Oceanogr 43: 465-470.

Shimode S, Hiroe Y, Hidaka K, Takahashi K, Tsuda A (2009) Life history and ontogenetic vertical migration of Neocalanus gracilis in the western North Pacific Ocean. Aquat Biol 7: 295-306.

Shoden S, Ikeda T, Yamaguchi A (2005) Vertical distribution, population structure and life cycle of Eucalanus bungii (Copepoda: Calanoida) in the Oyashio region, with notes on its regional variations. Mar Biol 146: 497-511.

Speekmann CL, Nunez BS, Edward J, Buskey EJ (2007) Measuring RNA:DNA ratios in individual Acartia tonsa (Copepoda). Mar Biol 151: 759-766.

Tsuda A, Saito H, Kasai H (2004) Life histories of Eucalanus bungii and Neocalanus cristatus (Copepoda: Calanoida) in the western subarctic Pacific Ocean. Fish Oceanogr 13: 10-20.

Verity PG, Smetacek V (1996) Organism life cycles, predation, and the structure of marine pelagic ecosystems. Mar Ecol Prog Ser 130: 277-293.

Vidal ÉAG, DiMarco P, Lee P (2006) Does the nutritional condition limit survival potential of sardine Sardina pilchardus (Walbaum, 1792) larvae off the north coast of Spain? RNA/ DNA ratios and their variability. Aquaculture 260: 94-105.

Wagner MM, Durbin EG, Buckley LJ (1998) RNA:DNA ratios as indicators of nutritional condition in the copepod Calanus finmarchicus. Mar Ecol Prog Ser 162: 173-181.

Wagner MM, Campbell RG, Boudreau CA, Durbin EG (2001) Nucleic acids and growth of Calanus finmarchicus in the laboratory under different food and temperature condition. Mar Ecol Prog Ser 221: 185-197.

Welschmeyer NA (1994) Fluorometric analysis of chlorophyll $a$ in the presence of chlorophyll $b$ and phaeopigments. Limnol Oceanogr 39: 1985-1992.

Yamamura O, Honda S, Shida O, Hamatsu T (2002) Diets of walleye Pollock Theragra chalcogramma in the Doto area, northern Japan: Ontogenetic and seasonal variations. Mar Ecol Prog Ser 238: 187-198.

Yebra L, Hernández-Léon S (2004) Aminoacyl-tRNA synthetases activity as a growth index in zooplankton. J Plankton Res 26: 351-356.

Yebra L, Kobari T, Sastri AR, Gusmão F, Hernández-León F (in press) Advances in biochemical indices of zooplankton production. Adv Mar Biol. 